\title{
Influence of Nutrient Management Approaches on Soil Enzyme Activity, Soil Microbial Population and Grain Yield of Dry Direct Seeded Rice
}

\author{
Raghavendra $^{1 *}$, K. Narayana Rao ${ }^{1}$, Mahadeva Swamy ${ }^{2}$ and S. P. Wani ${ }^{3}$ \\ ${ }^{1}$ Department of Soil Science and Agricultural Chemistry, University of Agricultural Sciences, \\ Raichur-584 104, Karnataka, India \\ ${ }^{2}$ Department of Agricultural Microbiology, College of Agriculture Raichur, Karnataka, India \\ ${ }^{3}$ Research Program Director - Asia and Theme Leader-ICRISAT Development Center, \\ Patancheru, Hyderabad-502 324, Telangana, India \\ *Corresponding author
}

\section{A B S T R A C T}

Nutrient supply and availability during crop growth influences various microbial mediated biochemical reactions and nutrient transformations. Studies were conducted during kharif

Keywords

Dry DSR, Enzyme

Activity, Soil

Microbial Population,

Grain yield, SSNM

\section{Article Info}

Accepted:

20 May 2018

Available Online:

10 June 2018 season of 2015-16 and 2016-17 in the farmer field of Vijayanagar camp, tq/dist: raichur, to study the influence of different nutrient management approaches on soil enzyme activity, soil microbial population and grain yield of dry DSR. Dehydrogenase activity, a key biochemical indicator, was higher (12.09 $\mu \mathrm{g}$ TPF formed $\mathrm{g}^{-1}$ soil $\left.^{-1} \mathrm{~h}^{-1}\right)$ with application of nutrients as per SSNM approach for targeted yield of $55 \mathrm{q} \mathrm{ha}^{-1}$ in Dry DSR. Farmers' practice of excessive fertilizer application had negative impact on dehydrogenase activity. The highest phosphatase activity (14.91 $\mu \mathrm{g}$ PNP $\mathrm{g}^{-1} \mathrm{soil} \mathrm{hr}^{-1}$ ) of soil was found with application of nutrients as per targeted yield approach as compared to absolute control $\left(9.47 \mu \mathrm{g}\right.$ PNP g ${ }^{-1}$ soil $\left.\mathrm{hr}^{-1}\right)$. Application of nutrients as per SSNM approach for targeted yield of $55 \mathrm{q} \mathrm{ha}^{-1}$ for Dry DSR registered significantly higher soil microbial population viz., bacterial $\left(25.73 \times 10^{6} \mathrm{cfu} \mathrm{g}^{-1}\right.$ of soil), fungal $\left(8.62 \times 10^{3} \mathrm{cfu}^{-1}\right.$ of soil) and actinomycetes $\left(10.14 \times 10^{4} \mathrm{cfu} \mathrm{g}^{-1}\right.$ of soil) and significantly higher the grain and straw yield (54.73 and $68.38 \mathrm{q} \mathrm{ha}^{-1}$, respectively) of dry DSR over farmers practice and other soil test methods.

\section{Introduction}

Dry direct seeded rice (Dry DSR) is method establishing rice with limited water supply, labour requirement and optimum nutrients. It has becoming a boon for tail-end farmers of command areas of Tungabhadra (TBP) where, water supplies are limited. The actual yield potentiality of Dry DSR had not been achieved because of existing fertilizer recommendation, as it consist of fixed rates and timing of $\mathrm{N}, \mathrm{P}$ and $\mathrm{K}$ for vast areas of production. Such recommendations are in practice over the years in large areas. But crop growth and crop need for supplemental nutrients are strongly influenced by genotype, soil type and climate which can vary greatly among fields, seasons and years. A judicious use of fertilizers is essential since the cost of 
fertilizers has gone up very high in recent years. Fertilizer requirements of different crops vary due to their differential production potential and ability to mine nutrients from native and fertilizer sources. On the other hand, excess application of fertilizer has its own limitation in promoting vegetative growth. The haphazard fertilization results in increasing the amount of nutrients not needed by the plant and increases the fertilizer costs of the farmer unnecessarily (Rajan et al., 2005). Though chemical fertilizers increase crop production but their overuse has resulted in hardening of the soil, adversely affected its health and fertility and replenishment potential. Soil is the habitat of a diverse array of organisms which include both micro flora and fauna, and this soil biodiversity help it to maintain its health and make it resilient to pressure due to intensive cropping. Soil micro organisms play a very important role in soil fertility not only because of their ability to carry out biochemical transformation but also due to their importance as a source and sink of mineral nutrients (Jenkinson and Ladd, 1981). The soil microbial community is involved in numerous ecosystem functions, such as nutrient cycling and organic matter decomposition, and plays a crucial role in the terrestrial carbon cycle (Schimel, 1995). The microbial communities possesses potential for rapid growth and turnover, means the microbial community is a more reactive component of a terrestrial ecosystem to external stress than plants and animals (Panikov, 1999). Application of organic fertilizers is one of important practical measures to improve soil fertility. In addition to providing necessary nutrients for crops and improving soil physico-chemical properties, organic fertilizer is able to enhance soil microbial activity of soil, such as improving activity of soil enzymes and increasing soil microbial biomass (Lv et al., 2005). Keeping foresaid points in mind, an experiment carried out to study the influence of different nutrient management approaches on soil enzyme activity, soil microbial population and grain yield of dry direct seeded rice

\section{Materials and Methods}

The field experiments was conducted during kharif season of 2015-16 and 2016-17, in the farmer field of Vijayanagar camp, Dist/Tq: Raichur, which is situated on the latitude of $16^{\circ} 11^{\prime}$ North, longitude of $77^{\circ} 13^{\prime}$ East and at an elevation of 393 meters above mean sea level and is located in the North Eastern Dry Zone (Zone-2) of Karnataka, India. The soil of the experimental site was deep black clay in texture (Sand $36.47 \%$, silt $10.75 \%$ and clay $52.80 \%$ ) with a bulk density of $1.12 \mathrm{Mg} \mathrm{m}^{-3}$ and water holding capacity 60.45 per cent. The soil $\mathrm{pH}$ was 8.20 with electrical conductivity of $0.69 \mathrm{dS} \mathrm{m} \mathrm{m}^{-1}$. The organic carbon content was medium $\left(6.82 \mathrm{~g} \mathrm{~kg}^{-1}\right)$. The soil was low in available nitrogen $(192.36 \mathrm{~kg}$ $\left.\mathrm{ha}^{-1}\right)$, high in available phosphorus $(74.68 \mathrm{~kg}$ $\left.\mathrm{ha}^{-1}\right)$, potassium (348.00 $\left.\mathrm{kg} \mathrm{ha}{ }^{-1}\right)$, sulphur (21.20 mg kg-1), exchangeable calcium and magnesium 37.54 and $10.75 \mathrm{c} \mathrm{mol}\left(\mathrm{p}^{+}\right) \mathrm{kg}^{-1}$ and low in DTPA extractable $\mathrm{Zn}\left(0.46 \mathrm{mg} \mathrm{kg}^{-}\right.$ $\left.{ }^{1}\right)$ and $\mathrm{Fe}(3.84 \mathrm{mg} \mathrm{kg}$ ), high in DTPA extractable $\mathrm{Cu}$ and $\mathrm{Mn}$ were 1.23 and $2.40 \mathrm{mg}$ $\mathrm{kg}^{-1}$, respectively. BPT 5204 used as a test crop variety.

The experiment was laid out in RCBD included ten treatments consisted of $\mathrm{T}_{1}$ : Absolute control (00: 00: $00 \mathrm{NPK} \mathrm{kg} \mathrm{ha}{ }^{-1}$ ), $\mathrm{T}_{2}$ : Recommended dose fertilizer (100: 50: 50 NPK kg ha ${ }^{-1}$ ), $\mathrm{T}_{3}$ : Farmers practice (246: 166: $60 \mathrm{~kg}$ NPK kg ha-1), $\mathrm{T}_{4}$ : Soil test laboratory method (112.5: 37.5: 37.5 NPK kg ha ${ }^{-1}$ ), $\mathrm{T}_{5}$ : STCR approach targeted yield $45 \mathrm{q} \mathrm{ha}^{-1}$ (99: 00: 60 NPK kg ha ${ }^{-1}$, $\mathrm{T}_{6}$ : STCR approach targeted yield $55 \mathrm{q} \mathrm{ha}^{-1}$ (134: 28: 80 NPK kg $\left.\mathrm{ha}^{-1}\right), \mathrm{T}_{7}:$ SSNM approach targeted yield $45 \mathrm{q}$ $\mathrm{ha}^{-1}$ (123: 35: 95 NPK kg ha ${ }^{-1}$ ), T 8 : SSNM approach targeted yield $55 \mathrm{q} \mathrm{ha}^{-1}$ (150: 43: 115 $\mathrm{kg}$ NPK kg ha ${ }^{-1}$ ), $\mathrm{T}_{9}$ : Nutrient expert approach 
targeted yield $45 \mathrm{q} \mathrm{ha}^{-1}$ (100: 22: $38 \mathrm{NPK} \mathrm{kg}$ $\left.\mathrm{ha}^{-1}\right), \mathrm{T}_{10}$ : Nutrient expert approach targeted yield $55 \mathrm{q} \mathrm{ha}^{-1}$ (118: 28: $45 \mathrm{NPK} \mathrm{kg} \mathrm{ha}^{-1}$ ). In Farmers practice treatment $\left(\mathrm{T}_{3}\right)$ fertilizer doses were arrived by conducting a survey from DSR growing farmers of Raichur, Manvi, Sindhanur, Sirguppa, Gangavathi and surrounding areas of UAS Raichur for their nutrient management. The outcome of the survey revealed that very excessive and high doses of nutrients/fertilizers are being used as against the state recommendation. FYM at the rate of 7 tonnes per hectare was applied 15-20 days before sowing to all pre-marked plots except absolute control and incorporated in soil.

The calculated NPK fertilizer as per different treatments, were applied in splits doses during different nutrient demand stages of DSR. i.e initial $1 / 4^{\text {th }}$ of nitrogen, entire dose of phosphorus and half dose of calculated potassium were applied at early, 25 to 30 days after sowing, in the form of urea, diammonium phosphate (DAP) and muriate of potash (MOP), later on $1 / 4^{\text {th }}$ of nitrogen, were applied at active tillering stage, and $1 / 4^{\text {th }}$ of nitrogen were applied at early panicle initiation stage. $50 \%$ potash and $1 / 4^{\text {th }}$ of nitrogen were applied at heading stage. As per soil test result the experimental site was deficient in zinc and iron, so that zinc was applied to experimental site in the form of $\mathrm{ZnSO}_{4}$ at the rate of $25 \mathrm{~kg} \mathrm{ha}^{-1}$ along with first dose of nitrogen application. Iron sulphate foliar sprayed (2-3 sprayings at 4-5 days intervals) at the rate of 0.5 per cent to correct iron deficiency in Dry-DSR during early growth stage except control. FYM at the rate of 7 tonnes per hectare was applied 15-20 days before sowing except absolute control and incorporated in soil. Soil samples were collected at harvesting stage and were processed for enzyme assay following the standard procedures viz., dehydrogenase enzyme activity (Casida et al., 1964), phosphatase (alkaline) enzyme activity (Evazi and Tabatabai, 1979). The enumeration of total bacteria, fungi and actinomycetes in free rhizosphere were determined by serial dilution and agar plate method (Pramer and Schmidt, 1964). The enumerated microbial population was expressed as $\log 10 \mathrm{CFU} \mathrm{g}{ }^{-1}$ of soil. Grain yield and straw yield of Dry DSR was recorded from net plot area converted into quintals per hectare. The response of crop was similar in both the years. Therefore, only pooled data of two years results are discussed.

\section{Results and Discussion}

\section{Effect of different nutrient management approaches on soil enzyme activity (Fig. 1)}

The biochemical properties of soil have often been proposed as early and sensitive indicators of soil ecosystem health (Oliveira and Pampulha, 2006). Activities of soil enzymes indicate the direction and strength of all kinds of biochemical processes in soil and act as key biological indicator of soil. Soil enzymes play an essential role in energy transfer, environmental quality, organic matter decomposition, nutrient cycling and crop productivity (Tabatabai, 1969; Kumar et al., 1992). Measurement of enzymes activity in combination with count of number of key microorganisms provides sensitive information of the changes occurring in soil (Brookees, 1995). Fertilizer doses tested in Dry DSR showed remarkable influence on soil enzyme activity at harvesting stage and activity of different enzymes is discussed in the following sections.

\section{Dehydrogenase activity (DHA) (Table 1)}

Dehydrogenase activity is an indicator of overall soil microbial activity and reflects the total scope of activity of soil microflora (Nannipieri et al., 2003). Significantly highest $\left(12.09 \mu \mathrm{g}\right.$ TPF formed $\mathrm{g}^{-1}$ of soil $\mathrm{hr}^{-1}$ ) 
dehydrogenase activity was noticed in treatment receiving nutrient application as per SSNM approach targeted yield of $55 \mathrm{q} \mathrm{ha}^{-1}$. This was mainly due to the application of balanced levels of NPK fertilizers as per SSNM approach in combination with FYM resulted in higher enzymatic activity.

These results accordance with the findings of Singaram and Kamalakumari (1995) they found that activities of soil enzymes were found to be more pronounced with application higher levels of NPK fertilizers in combination with FYM. It was found on par with STCR approach targeted yield of $55 \mathrm{q} \mathrm{ha}^{-}$ 1 and SSNM approach targeted yield of $45 \mathrm{q}$ $\mathrm{ha}^{-1}$ (11.84 and $11.63 \mu \mathrm{g}$ TPF formed $\mathrm{g}^{-1}$ of soil $\mathrm{hr}^{-1}$, respectively) and it was significantly superior over rest of the treatments and lowest dehydrogenase activity was observed in absolute control $\left(5.68 \mu \mathrm{g}\right.$ TPF formed $\mathrm{g}^{-1}$ of soil $\mathrm{hr}^{-1}$ ).

Increase in dehydrogenase activity with application of the macro elements was presumably due to increased rhizosphere development and activity (Bednarz and Krzepilko, 2009). But, excessively high doses of fertilizers showed a negative impact on activity of dehydrogenase as evidenced by the significantly lower DHA in farmers' practice. Inhibition of dehydrogenase activity with higher doses of mineral fertilizers was reported by Zakarauskaite et al., (2008) in sandy and silty loams.

\section{Alkaline phophatases activity (Table 1)}

Phosphatase activity is important as is related to phosphorus cycle in the soil (Bhadoria et al., 2011). Phosphatase enzymes are believed to be involved in mineralizing organic phosphorus to inorganic phosphorus. Activities of alkaline phosphatases in the present study were significantly influenced by various treatments. The highest phosphatase activity (14.91 $\mu \mathrm{g}$ PNP g ${ }^{-1}$ soil $\mathrm{hr}^{-1}$ ) of soil was found with application of nutrients as per SSNM for targeted yield of $55 \mathrm{q} \mathrm{ha}^{-1}$ as compared to absolute control $\left(9.47 \mu \mathrm{g} \mathrm{PNP} \mathrm{g}^{-1}\right.$ soil hr-1) and other soil test based methods (Table 1.) Shedzhen et al., (1991) found that application of N, P, K, B, Co, Mo. Zn, Mn and $\mathrm{Cu}$ increased the phosphatase activity.

These results are also corroborates with the findings of Apoorva et al., (2010) and SalinasGarcia et al., (2002). Addition of higher levels of fertilizers doses resulted in slight reduced the activity of these enzymes. Application of fertilizer in farmers practice resulted in decline the phosphatise activity as compared SSNM approach for targeted yield of $55 \mathrm{q} \mathrm{ha}^{-1}$.

\section{Effect of nutrient management practices on grain yield dry DSR (Table 2)}

The yield potential of the crop can be exploited to the maximum only when the nutrient requirements are fully met. On the other hand, excess application of fertilizer has its own limitations. In the present study, grain yield of dry DSR was significantly influenced by the different fertilizer doses. Application of nutrients through targeted yield approach exerted significant influence on the grain and straw yield of Dry DSR. Significantly higher grain (54.73 q ha ${ }^{-1}$ ) and straw (68.38 q ha ${ }^{-1}$ ) (Table 2) yield of Dry DSR was recorded with treatment receiving SSNM approach for targeted yield of $55 \mathrm{q} \mathrm{ha}^{-1}$ as compared to farmers' fertilizer practice and other soil test methods.

The higher grain yield can be attributed to the ability of targeted yield approaches to satisfy the nutrient demand of crop more efficiently. The higher grain yield of Dry DSR was also due to better translocation of photosynthates from source to sink and higher growth and yield attributing characters. 
Table.1 Effect of different nutrient management approaches on soil enzyme activity and grain yield of dry direct seeded rice (Pooled data of 2 years)

\begin{tabular}{|c|c|c|c|c|}
\hline Treatments & $\begin{array}{l}\text { Alkaline phosphatase } \\
\left(\mu \mathrm{g} \text { PNP } \mathrm{g}^{-1} \mathrm{hr}^{-1}\right)\end{array}$ & $\begin{array}{l}\text { Dehydrogenase } \\
\left(\mu \mathrm{g} \text { TPF } \mathrm{g}^{-1} \mathrm{hr}^{-1}\right)\end{array}$ & $\begin{array}{l}\text { Grain yield } \\
\qquad\left(\mathbf{q} \mathbf{h a}^{-1}\right)\end{array}$ & $\begin{array}{l}\text { Straw yield }(\mathbf{q} \\
\left.\text { ha }^{-1}\right)\end{array}$ \\
\hline $\mathbf{T}_{1}:$ Absolute control & 9.47 & 5.68 & 21.41 & 27.58 \\
\hline $\mathrm{T}_{2}: \mathrm{RDF}$ & 11.60 & 9.51 & 44.25 & 57.09 \\
\hline $\mathrm{T}_{3}:$ Farmers practice & 13.23 & 10.60 & 50.39 & 62.96 \\
\hline $\mathrm{T}_{4}: \mathrm{STL}$ method & 11.26 & 7.46 & 46.94 & 58.64 \\
\hline $\mathrm{T}_{5}: \mathrm{STCR}$ approach $\left(45 \mathrm{q} \mathrm{ha}^{-1}\right.$ yield targeted) & 10.47 & 6.68 & 39.01 & 48.75 \\
\hline $\mathrm{T}_{6}:$ STCR approach $\left(55 \mathrm{q} \mathrm{ha}^{-1}\right.$ yield targeted $)$ & 13.84 & 11.84 & 51.79 & 64.71 \\
\hline $\mathrm{T}_{7}:$ SSNM approach (45 q ha ${ }^{-1}$ yield targeted) & 12.61 & 11.63 & 48.48 & 60.58 \\
\hline $\mathrm{T}_{8}:$ SSNM approach $\left(55 \mathrm{q} \mathrm{ha}^{-1}\right.$ yield targeted $)$ & 14.91 & 12.09 & 54.73 & 68.55 \\
\hline $\begin{array}{l}\text { T9: Nutrient expert approach ( } 45 \mathrm{q} \mathrm{ha}^{-1} \text { yield } \\
\text { targeted) }\end{array}$ & 11.02 & 8.07 & 42.41 & 52.99 \\
\hline $\begin{array}{l}\mathrm{T}_{10} \text { : Nutrient expert approach }\left(55 \mathrm{q} \mathrm{ha}^{-1} \text { yield }\right. \\
\text { targeted }\end{array}$ & 11.75 & 8.16 & 47.82 & 59.74 \\
\hline S. Em. \pm & 0.02 & 0.23 & 2.50 & 3.05 \\
\hline C.D. at $5 \%$ & 0.05 & 0.68 & 7.42 & 9.05 \\
\hline
\end{tabular}

Note: FYM @ $7 \mathrm{t} \mathrm{ha}^{-1}$ were applied for all treatments except absolute control 
Table.2 Microbial population at harvest stage of Dry DSR as influenced by different nutrient management approaches (Pooled data of 2 years)

\begin{tabular}{|c|c|c|c|}
\hline Treatments & $\begin{array}{c}\text { Bacteria } \\
\left(\mathbf{1 0}^{6} \mathrm{cfu} \mathrm{g}^{-1}\right)\end{array}$ & $\begin{array}{l}\text { Fungi } \\
\left(10^{3} \mathrm{cfu} \mathrm{g}^{-1}\right)\end{array}$ & $\begin{array}{l}\text { Actinomycetes } \\
\left(10^{4} \mathrm{cfu} \mathrm{g}^{-1}\right)\end{array}$ \\
\hline $\mathrm{T}_{1}$ : Absolute control & 14.84 & 5.34 & 5.66 \\
\hline $\mathrm{T}_{2}: \mathrm{RDF}$ & 18.77 & 7.83 & 8.11 \\
\hline $\mathrm{T}_{3}$ : Farmers practice & 19.55 & 7.51 & 8.76 \\
\hline $\mathrm{T}_{4}:$ STL method & 17.67 & 7.28 & 8.31 \\
\hline $\begin{array}{l}\mathrm{T}_{5}: \text { STCR approach } \\
\left(45 \mathrm{q} \mathrm{ha}^{-1} \text { yield targeted) }\right. \\
\end{array}$ & 17.62 & 6.76 & 6.96 \\
\hline $\begin{array}{l}\mathrm{T}_{6}: \text { STCR approach } \\
\left(55 \mathrm{q} \mathrm{ha}^{-1} \text { yield targeted) }\right.\end{array}$ & 23.11 & 7.34 & 9.45 \\
\hline $\begin{array}{l}\mathrm{T}_{7}: \text { SSNM approach } \\
\text { (45 } \mathrm{q} \mathrm{ha}^{-1} \text { yield targeted) }\end{array}$ & 23.70 & 8.18 & 9.74 \\
\hline $\begin{array}{l}\mathrm{T}_{8}: \text { SSNM approach } \\
\text { (55 } \mathrm{q} \mathrm{ha}^{-1} \text { yield targeted) } \\
\end{array}$ & 25.73 & 8.62 & 10.14 \\
\hline $\begin{array}{l}\text { T9: Nutrient expert approach } \\
\text { (45 q ha } \mathrm{hield} \mathrm{targeted)}^{-1} \text { yield } \\
\end{array}$ & 18.14 & 6.72 & 7.65 \\
\hline $\begin{array}{l}\mathrm{T}_{10}: \text { Nutrient expert approach } \\
\text { (55 } \mathrm{q} \mathrm{ha}^{-1} \text { yield targeted) }\end{array}$ & 21.05 & 7.67 & 8.53 \\
\hline S. Em. \pm & 1.13 & 0.35 & 0.29 \\
\hline C.D. at $5 \%$ & 3.37 & 1.05 & 0.85 \\
\hline
\end{tabular}

Note: FYM @ 7 FYM at the rate of 7 tonnes per hectare was applied 15-20 days before sowing to all pre-marked plots except absolute control and incorporated in soil.

Fig.1 Soil enzyme activities at harvest of Dry DSR as influenced by different nutrient management approaches (Pooled data)

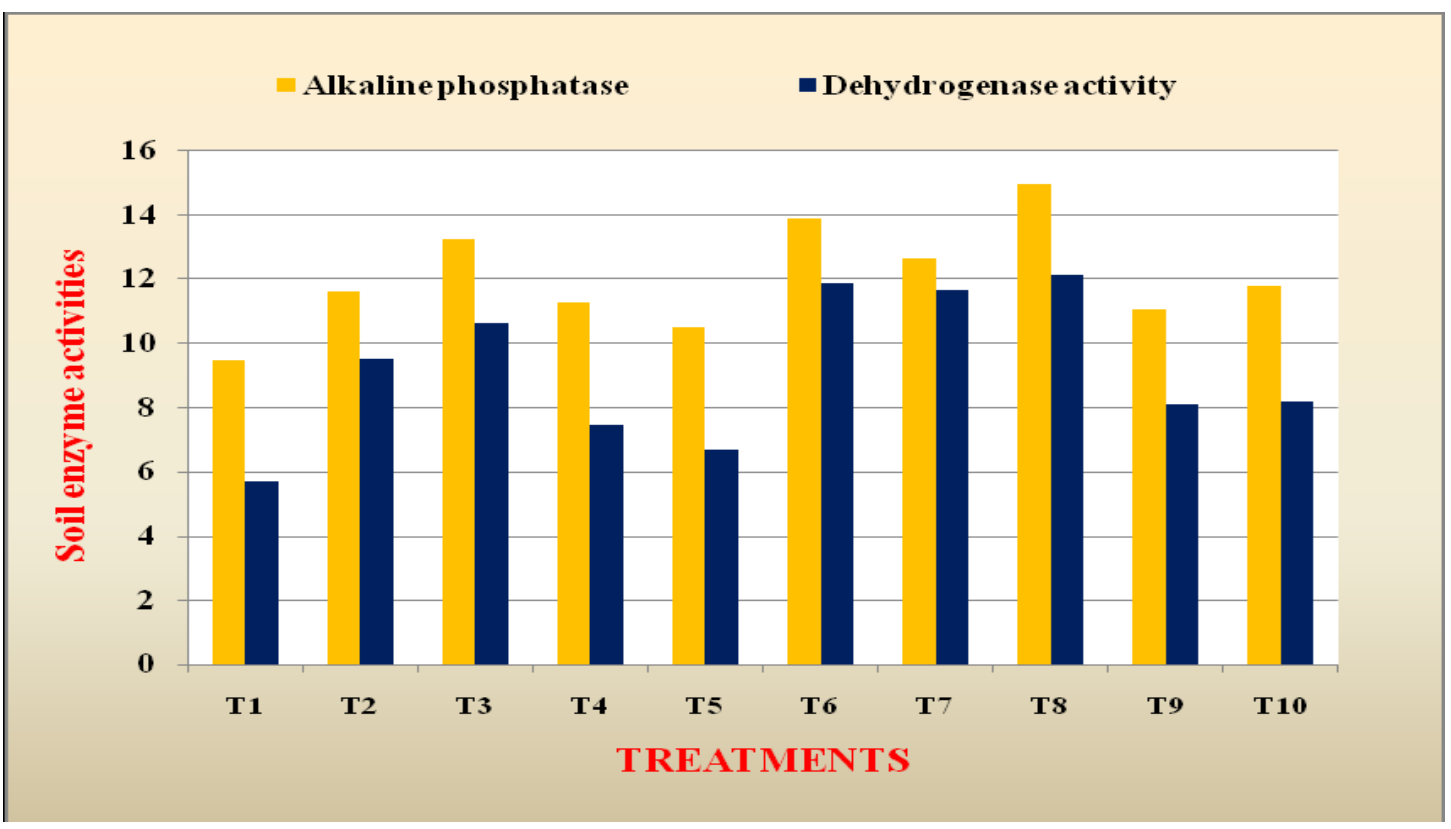


Fig.2 Microbial population at harvest of Dry DSR as influenced by different nutrient management approaches (Pooled data)

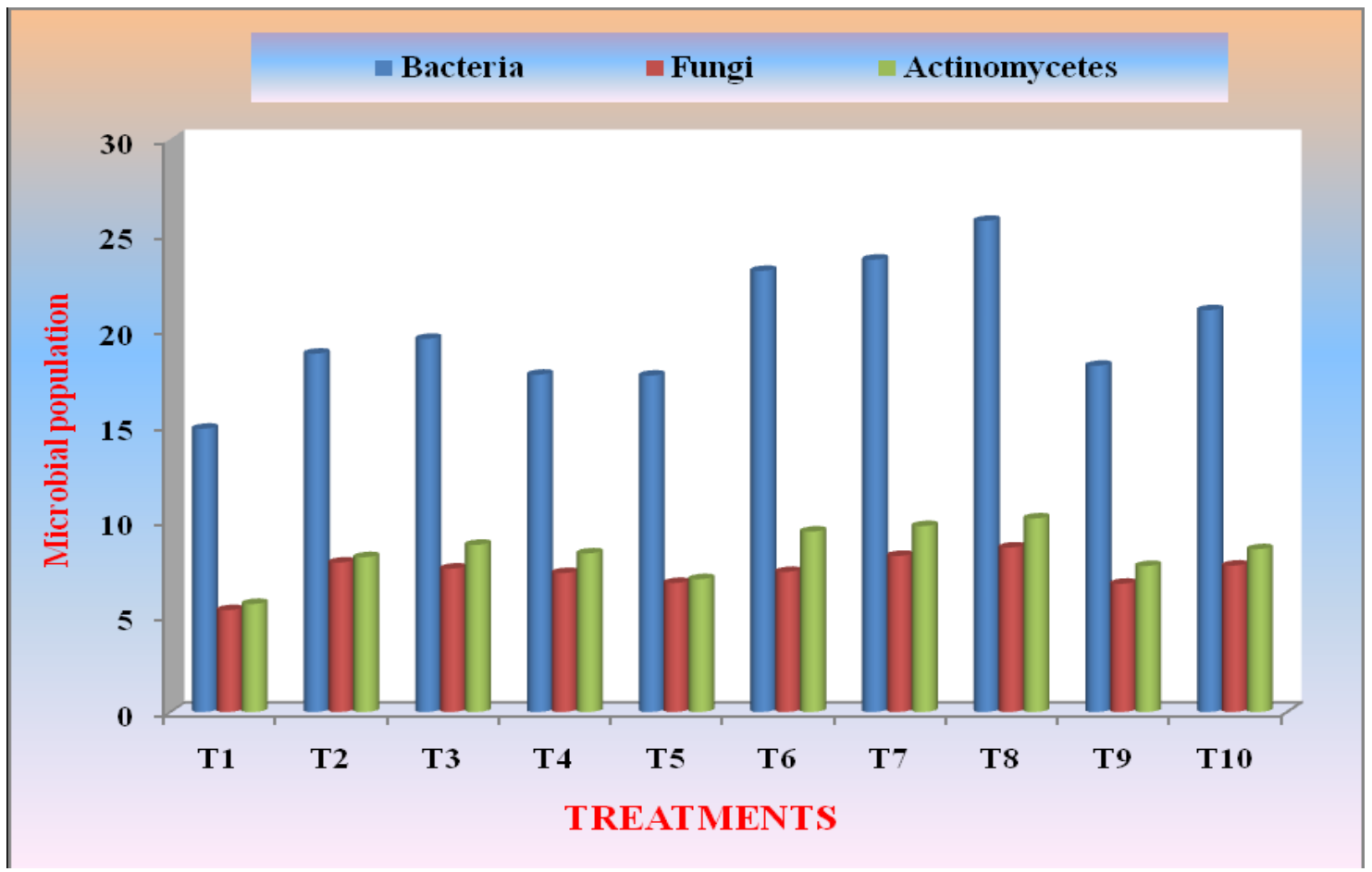

The results are in confirmation with the findings of Police Patil (2011) application of nutrients as per SSNM for targeted yield of $6.5 \mathrm{t} \mathrm{ha}^{-1}$ in aerobic rice recorded significantly higher grain yield $\left(5903 \mathrm{~kg} \mathrm{ha}^{-1}\right)$ and straw yield (7279 $\mathrm{kg} \mathrm{ha}^{-1}$ ) as compared other treatments.

Similarly Dhillon et al., (2006) reported higher grain yield $\left(46.0 \mathrm{q} \mathrm{ha}^{-1}\right)$ with the application of fertilizer based on targeted yield (45.0 $\left.\mathrm{q} \mathrm{ha}^{-1}\right)$ approach when compared to farmers' practice, RDF and soil test based applications.

These results are also coroborated with the findings of Doberman et al., (2002), Keram et al., (2012), Umesh and Singh et al., (2014). However, it was found on par with $\mathrm{T}_{6}(51.79$ $\left.\mathrm{q} \mathrm{ha}^{-1}\right)$ followed by $\mathrm{T}_{3}\left(50.38 \mathrm{q} \mathrm{ha}^{-1}\right), \mathrm{T}_{7}$ (49.01 q ha $\mathrm{q}^{-1}$ and $\mathrm{T}_{10}\left(47.81 \mathrm{q} \mathrm{ha}^{-1}\right)$. The lowest grain yield was recorded in unfertilized plots (21.40 $\left.\mathrm{q} \mathrm{ha}^{-1}\right)$.

\section{Effect of nutrient management practices on} soil microbial population (Table 2) Fig. 2

Enumeration of bacteria, fungi and actinomycetes in soil at harvest of the crop was significantly influenced by the different nutrient management approaches are presented in Table 2 and Fig. 2. Different nutrient management approaches were found to be significant with respect to bacterial population at harvest of rice. It was observed that, at harvest of crop enumerated bacterial population was significantly higher $\left(25.73 \times 10^{6} \mathrm{cfu}^{-1}\right.$ of soil) with treatment receiving SSNM approach targeted yield of $55 \mathrm{q} \mathrm{ha}{ }^{-1}$. The rise in the microbial populations after harvest could be due to favourable environment and the availability of food sources at that stage due to the residual organic materials and balanced dose of fertilizers especially $\mathrm{N}$ and $\mathrm{K}$ along with FYM, which has resulted in more organic carbon accumulation and lead to more 
microbial activity. The results are in line with the earlier findings of Salinas-Garcia et al., 2002 and Gayathry, 2006. it was found on par with SSNM approach targeted yield of $45 \mathrm{q}$ $\mathrm{ha}^{-1}$ and STCR approach targeted yield of 55 $\mathrm{q} \mathrm{ha}^{-1}\left(23.70\right.$ and $23.11 \times 10^{6} \mathrm{cfu} \mathrm{g}^{-1}$ of soil respectively). It was significantly superior over the rest of other treatments and lowest enumerated bacterial population was observed in absolute control $\left(14.84 \times 10^{6} \mathrm{cfu} \mathrm{g}^{-1}\right.$ of soil).

Similarly the fungal and actinomycetes population was significantly higher with SSNM for targeted yield of $55 \mathrm{q} \mathrm{ha}^{-1}$ (8.62 cfu $\times 10^{3} \mathrm{~g}^{-1}$ and $10.14 \mathrm{cfu} \times 10^{4} \mathrm{~g}^{-1}$, respectively) followed by SSNM for targeted yield of $45 \mathrm{q}$ $\mathrm{ha}^{-1}\left(8.18 \mathrm{cfu} \times 10^{3} \mathrm{~g}^{-1}\right.$ and $9.74 \mathrm{cfu} \times 10^{4} \mathrm{~g}^{-1}$, respectively) and STCR for targeted yield of $55 \mathrm{q} \mathrm{ha}^{-1}\left(7.34 \mathrm{cfu} \times 103 \mathrm{~g}^{-1}\right.$ and $9.45 \mathrm{cfu} \times 10^{4}$ $\mathrm{g}^{-1}$, respectively), (Table 2 ). This may due to the positive influence of $\mathrm{N}$ and $\mathrm{K}$ from inorganic source at initial stages by masking the initial inhibitory effect of organic acids produced during decomposition which promoted the rapid multiplication of microflora in the soil. This is in line with the findings of Uphoff (2006).

Application of nutrients as per SSNM approach for targeted yield of $55 \mathrm{q}$ per hector along 7 tons of FYM resulted in increase in soil enzyme activity, soil microbial population and grain yield of dry DSR.

\section{References}

Apoorva, K. B., Prakash, S. S., Rajesh, N. L. and Nandini, B., STCR approach for optimizing integrated plant nutrient supply on growth, yield and economics of finger millet (Eleusine coracana). European J. Biol. Sci., 4(1): 19-27 (2010).

Bednarz, B. S. and Krzepilko, A. Effect of different fertilization on enzyme activity in rhizosphere and non-rhizosphere of
Amaranth. Intl Agrophys. 23: 409-412 (2009).

Bhadoria, P. B. S., Basu, M. and Mahapatra, S. C. 2011. Study of microbial population and enzyme activities in intercropped peanut rhizosphere with different nutrient application. $\mathrm{Br}$. Biotechnol. J. 1(2): 29-45.

Brookes, P. C. 1995. The use of microbial parameters in monitoring soil pollution by heavy metal. Biol. Fert. Soils. 19: 269-279.

Cassida, L. E. Jr., Klein, D. A. and Santoro, T., 1964, Soil dehydrogenase activity. Soil Sci., 98: 371-376.

Doberman, A., Witt, C. and Dawe, D., 2002, Performance of site specific nutrient management in intensive rice cropping systems of Asia. Better Crops Int., 16(1): 25-30.

Evazi, Z. and Tabatabai, M. A., 1979, Phosphatase in soils. Soil Biol Biochem., 9: 167-172.

Jenkinson, D.S. and Ladd, J.N. 1981. Microbial Biomass in Soil: Measurement and Turnover. In: Soil Biochemistry, Paul, E.A. and J.N. Ladd (Eds.). Marcel Dekker, New York, USA. pp: 415-471.

Keram, K.S., Puri, G. and Sawarkar, S. D., 2012, Assessment of soil test based fertilizer recommendation under ricewheat cropping sequence and its impact on soil quality under agroclimatic condition of Kymore plateau zone of Madhya Pradesh, India. JNKVV Res. J., 46(1): 62-68.

Kumar, J. D., Sharma, G. D. and Mishra, R. R. 1992. Soil microbial population numbers and enzyme activities in relation to altitude and forest degradation. Soil Biol. Biochem. 24: 761-767.

Lv, W.G., Huang, Q.W., Shen, Q.R. 2005. The effect of organic fertilizer and organic-inorganic fertilizer application 
on soil enzymes activities during watermelon growing period. J. Nanjing Agri. Univ., 28: 67-71.

Nannipieri, P., Ascher, J., Ceccherini, M. T., Landi, L., Pietramellara, G. and Renella, G. 2003. Microbial diversity and soil functions. Eur. J. Soil. Sci. 54: 816-824.

Oliveira, A. and Pampulha, M. E. 2006. Effects of long term heavy metal contamination on soil microbial characteristics. J. Biosci. Bioeng. 102(3): 157-161.

Panikov, N.S. 1999. Understanding and prediction of soil microbial community dynamics under global change. Appl. Soil Ecol., 11: 161-176.

Police Patil, A. S., 2011, Yield maximization in aerobic rice through site specific nutrient management approach. Ph. D. Thesis, Univ. Agric. Sci., Bangalore.

Pramer, D. and Schmidt, E. L., 1964, Experimental soil microbiology. Burgers Publishing. Minneapolis, Minnesota, USA.

Rajan, A. R., Janaki, P., Appavu, K. and Vadivel A. 2005. Effect of fertilizer NPK and FYM on yield of cotton and nutrient status in black soil. Madras Agric. J. 92(4-6): 266-270.

Salinas-Garcia, J. R., Velazquez-Garcia, J. D., Gallardo-Valdez, A., Diaz-Mederos, P., Caballero-Hernandez, F., Tapia-Vargas, L. M. and Rosales-Robles, E., 2002, Tillage effects on microbial biomass and nutrient distribution in soils under rainfed corn production in centralwestern Mexico. Soil Tillage Res., 66: 143-152.

Schimel, D.S. 1995. Terrestrial ecosystem and carbon cycle. Global Change Biol., 1: 77- 91.

Singaram, C. P. and Kamalakumari, K., 1995, Long-term effect of FYM and fertilizers on enzyme dynamics of soil. J. Indian Soc. Soil Sci., 43: 378-381.

Tabatabai, M. A. and Bremner, J. M. 1969. Use of P-nitro phenyl phosphate for assay of soil phosphatase activity. Soil. Biol. Biochem. 1: 301-307.

Umesh, M. R., Manjunatha, N., Shankar, M. A. and Jagadeesha, N., 2014, Influence of nutrient supply levels on yield, nutrient uptake, grain quality and economics of corn (Zea mays L.) in Alfisols of Karnataka. Indian J. Dryland Agric. Res. \& Dev., 29(1): 73-78.

Uphoff, N., 2006, Thoughts on the history, principles and practices of SRI and on its importance for the present scenario. National Symposium on System of Rice Intensification - Present status and future prospects. 17-18 November, p. 310.

Zakarauskaite, D., Vaisvila, Z., Mtuzas, A., Grigaliuniene, K., Buivydaite, V. V., Vaisvalavicius, R. and Butkus, V. 2008. The influence of long-term application of mineral fertilizers on the biological activity of Cambisols. EKOLOGIA. 54(3): 173-178.

\section{How to cite this article:}

Raghavendra, K. Narayana Rao, Mahadeva Swamy and Wani S. P. 2018. Influence of Nutrient Management Approaches on Soil Enzyme Activity, Soil Microbial Population and Grain Yield of Dry Direct Seeded Rice. Int.J.Curr.Microbiol.App.Sci. 7(06): 2558-2567. doi: https://doi.org/10.20546/ijcmas.2018.706.302 